\title{
Development of technology for the construction of heat-efficient monolithic vaults from basalt fiber concrete
}

\author{
Dmitry Kazakov*, Aleksandr Tkachenko, Arben Arzumanov, Leonid Bolotskikh, and Andrey \\ Mishchenko \\ Voronezh state technical University, 394006, Voronezh, Russia
}

\begin{abstract}
The paper considers the issue of erection of structures of buildings and structures from monolithic dispersed-reinforced concrete, capable of performing not only a load-bearing, but also a protective function. The analysis of a number of dispersed-reinforced concretes with both structural and thermal insulation properties has been carried out. An increase in thermal efficiency is expected through the use of industrial porous aggregates. The technical indicators of samples of basalt-fiber-reinforced concrete with fillers: perlite and foam glass have been experimentally investigated. Experimental relationships are obtained that characterize the compressive and bending strength, as well as the thermal conductivity of the materials under study.
\end{abstract}

\section{Introduction}

The construction process as a whole is a complex of various types of work and needs their modernization and the introduction of new technologies in order to increase labor productivity. The main task of modern construction is to improve the construction process and the use of innovative building materials to ensure comfortable living conditions in buildings and structures.

A promising direction in the development of the investment and construction complex as a whole is the increase in energy efficiency as well as structures, achieved by improving the thermal performance of individual structures, as well as reducing energy costs during the construction process $[1,2]$.

One of the most widespread materials used in modern construction is concrete. In this case, the factor that determines the appropriateness of its use for the manufacture of individual structures and entire structures is its structural characteristics, such as compressive strength, tensile strength, bending strength, and workability.

At the same time, the modern level of science and technology makes it possible to expand the list of useful properties of this material by introducing effective components into its composition. Examples of the use of heat and chemical resistant, hydrophobic, light, etc. are

${ }^{*}$ Corresponding author: k_di@list.ru 
widely known. concrete. It is important to preserve the high mechanical characteristics of these materials, ensuring the possibility of their use as structural materials.

The world is constantly improving the properties of the main structural building material of concrete. One of the directions of this improvement is dispersed reinforcement [3]. From the current level of construction technology, the use of fiber-reinforced monolithic concrete structures is widely known [4].

Currently, various filaments (fibers) are used as dispersed reinforcement. Basalt fibers in the form of thin fibers are used increasingly for dispersed reinforcement [5-12]. In the case of the construction of vaulted monolithic structures, dispersed reinforcement successfully replaces the rod, allowing the construction of thin bearing and enclosing structures, reducing material consumption and, as a result, the cost of construction in general [13].

One of the technological features of the construction of monolithic vaulted structures is the high labor intensity of creating vaulted structures from several layers of different purposes, which are both load-bearing and enclosing structures, and must have not only high mechanical characteristics, but also sufficient thermal efficiency [14]. Basalt fiber concrete (hereinafter referred to as BFC) meets these requirements with a heat-efficient filler introduced into it. The authors propose a variant of manufacturing a monolayer arch from the specified material.

\section{Materials and Methods}

Resource and energy saving are priority areas for the development of scientific research in the field of building materials [15]. The effective compositions being developed should be distinguished by high heat engineering characteristics in comparison with the existing ones.

Lightweight aggregates can be used as an additive to a fiber cement matrix to reduce the thermal conductivity of concrete. At the moment, about $80 \%$ of the production of lightweight aggregate falls on expanded clay. The main advantage is the low cost of production, and, therefore, these properties make this material one of the most demanded in construction.

In the course of preliminary analytical studies of various thermal engineering materials currently used in construction and meeting the assigned tasks, expanded clay chips, perlite, vermiculite, foam glass, as well as a number of synthetic materials based on polystyrene were considered.

Structural and heat-insulating concrete is a concrete that contains a porous aggregate that acts as a heater. It belongs to the number of lightweight concrete, with average strength parameters and decent thermal insulation characteristics. This type of concrete is widely used in the construction of single-layer enclosing structures, in the insulation of walls and ceilings.

The preference in the use of structural and heat-insulating concrete is due to the following factors $[16,17]$ :

- possessing the highest strength characteristics, but less shrinkage and creep, by achieving a close density of concrete with aggregate;

- decrease in pressure on the base of the structure;

- decrease in thermal conductivity of structures, reducing heating costs;

- reduction of labor intensity of assembly and loading and unloading works.

As a result of the analysis of various, including cost, indicators, it was decided to focus on perlite and expanded glass.

Perlite is a material obtained by firing at a temperature of $900-1100^{\circ} \mathrm{C}$ of crushed rock of volcanic origin $[18,19]$. Under the influence of high temperatures, the volume of the substance increases by 4-20 times. The technical characteristics of pearlite are presented in table 1. 
Table 1. Physical and technical characteristics of expanded perlite.

\begin{tabular}{lcc}
\hline \multicolumn{1}{c}{ Parameter } & $\begin{array}{c}\text { Sand mark } \\
\mathrm{M}-75\end{array}$ & $\begin{array}{c}\text { Sand } \\
\text { mark } \\
\mathrm{M}-100\end{array}$ \\
$\begin{array}{l}\text { Bulk density } \mathbf{~} \mathbf{k g} / \mathbf{m}^{\mathbf{3}}, \text { not more than } \\
\text { Thermal conductivity at a temperature of } \mathbf{( 2 5} \pm \mathbf{5})^{\circ} \mathbf{C} \text { not more }\end{array}$ & 75 & 100 \\
than $\mathbf{W} / \mathbf{m}^{\circ} \mathbf{C}$ & 0.043 & 0.052 \\
$\begin{array}{l}\text { Grain composition, } \mathbf{m m} \\
\text { Moisture \% by mass, not more than }\end{array}$ & $0.16-1.25$ & $0.16-1.25$ \\
$\begin{array}{l}\text { Grain content more than } \mathbf{1 . 2 5} \mathbf{m m} \text { and less than } \mathbf{0 . 1 6 m m}, \text { not } \\
\text { more than \% by volume }\end{array}$ & 2 & 2 \\
\hline
\end{tabular}

Granular foam glass consists of closed pores and is distinguished by high mechanical strength, high frost resistance, and durability [20-24]. When using granulated foam glass as a heat-efficient additive, the material consumption of products is reduced by $30 \%$, the cost of production by $10 \%$, and the resistance to heat transfer increases by $80 \%$.

Foam glass is a dispersed system with a gas dispersion medium. The pressure of the gaseous medium in glass cells is much lower than atmospheric, because foaming occurs due to the release of gases by coke, anthracite and soot at high temperatures, of the order of $1000^{\circ}$ C. As a result of the processes of gassing and foaming of glass, the volume increases up to 10-14 times. The resulting material has sufficient strength and high ability to withstand mechanical stress. As a result, the resulting matrix of nodes and bonds of the foam glass structure is a spatial-volume configuration, which is capable of withstanding maximum loads at the lowest density.

Granular foam glass is a promising aggregate for lightweight concrete, as it has higher thermal performance compared to other porous aggregates. The characteristics of granulated foam glass are presented in table 2 .

Table2. Physical and technical characteristics of granulated foam glass.

\begin{tabular}{lcc}
\hline \multicolumn{1}{c}{ Parameter } & Unit of measurement & Value \\
Fractional composition & $\mathrm{mm}$ & $5-50$ \\
Bulk density & $\mathrm{kg} / \mathrm{m}^{3}$ & $150-300$ \\
Coefficient of thermal conductivity & $\mathrm{W} /(\mathrm{m} * \mathrm{~K})$ & $0,06-0,09$ \\
Water absorption by volume & $\%$ & $2-10$ \\
Compressive strength in the cylinder & $\mathrm{MPa}$ & $1,0-2,5$ \\
Application temperature & ${ }^{\circ} \mathrm{C}$ & $-50 \ldots+500$ \\
Lifespan & years & $45-200$ \\
\hline
\end{tabular}

Differences in granule size do not affect the thermal conductivity of the material.

The experimental program, developed in accordance with STST 10180-2012, STST 10181-2014, provided for the manufacture of a set of samples for each type of concrete: cubes in the amount of 6 pieces, with an edge length of $100 \mathrm{~mm}$, prisms in the amount of 6 pieces, measuring $40 \times 40 \times 160 \mathrm{~mm}$, prisms in the amount of 3 pieces, $150 \times 150 \times 20 \mathrm{~mm}$ in size from ordinary BFC, BFC with a filler - perlite and BFC with filler - foam glass.

Samples were made using the following materials:

1. Portland cement M 500 gray grade PC 500-D0 (CEM I) in accordance with STST 10178-85 and STST 30515-2013;

2. Quartz sand (grain size: $1-1.5 \mathrm{~mm}, 2.0-5.0 \mathrm{~mm}$ ) according to STST 8736-2014;

3. Expanded perlite sand M 100 (grain size: $0.16-1.25 \mathrm{~mm}$ ) according to STST 108322009

4. Granulated foam glass of the SHP 140 / 5-20 brand;

5. Plasticizer grade PKE 3135 according to STST 24211, STST 30459; 
6. Chopped basalt fiber of the BS-16-13.7-KV-0.5 / 1 grade according to TU-5952-00213307094-2008;

7. PVA-MB universal glue, TU 2242-011-39778023-2015.

The main indicators of fiber-reinforced concrete established by STST 26633-2012 are axial tensile strength class and compressive strength class. The specified characteristics were determined under compression $\left(\mathrm{R}_{\text {comp }}\right.$ ) - by testing cubes with dimensions of $100 \times 100 \times 100$ $\mathrm{mm}$, and in bending $\left(\mathrm{R}_{\text {ben }}\right)$ - by testing prisms $40 \times: \times 160 \mathrm{~mm}$. All samples were kept in normal temperature and humidity conditions (relative humidity $95-98 \%$, temperature $18-22{ }^{\circ} \mathrm{C}$ ).

Table 3 shows the compositions of the mixtures indicating the content of the main components. In the formulations of each test, the total volume of active matrix components was constant, i.e. "Mixed binder" (cement + modifier), water, fiber and aggregate fractions less than $0.63 \mathrm{~mm}$, but the ratio between binder and aggregate varied [23-26].

All samples of concrete mixes have high mobility - the spread of a standard cone - in the range of 70-75 cm and were distinguished by increased cohesion-non-segregation, which equates them to the category of self-compacting. Substitution of up to $12 \%$ of the "mixed binder" with fine aggregate had practically no effect on the rheological properties of the mixtures.

Table 3. Compositions of mixtures for making samples.

\begin{tabular}{|c|c|c|c|c|c|}
\hline \multirow[t]{2}{*}{ № } & \multirow{2}{*}{$\begin{array}{c}\text { Sample sketch and } \\
\text { test type }\end{array}$} & \multirow{2}{*}{$\begin{array}{l}\text { Number } \\
\text { of sam- } \\
\text { ples, pcs }\end{array}$} & \multicolumn{3}{|c|}{ Components $1 \mathrm{~m}^{3}$} \\
\hline & & & $\begin{array}{c}\text { Option } 1-\mathrm{BFC}+ \\
\text { perlite }\end{array}$ & $\begin{array}{c}\text { Option } 2 \text { - BFC + } \\
\text { foam glass }\end{array}$ & Option 3 - BFC \\
\hline 1 & $\begin{array}{l}\text { Compression, } \\
\text { cube } \\
100 \times 100 \times 100 \mathrm{~mm}\end{array}$ & 6 & $\begin{array}{l}\text { Portland cement- } \\
860 \mathrm{~kg} \\
\text { Sand- } 504 \mathrm{~kg} \\
\text { Water- } 3401 \\
\text { Fiber basalt- } 0,8 \\
\mathrm{~kg} \\
\text { Perlite- } 34 \mathrm{~kg} \\
\text { V / C } 0,4\end{array}$ & $\begin{array}{l}\text { Portland cement- } \\
860 \mathrm{~kg} \\
\text { Sand- } 620 \mathrm{~kg} \\
\text { Water- } 340 \mathrm{l} \\
\text { Fiber basalt- } 0,8 \\
\mathrm{~kg} \\
\text { Foam glass- } 80 \mathrm{~kg} \\
\mathrm{~V} / \mathrm{C} 0,4\end{array}$ & $\begin{array}{l}\text { Portland ce- } \\
\text { ment- } 860 \mathrm{~kg} \\
\text { Sand- } 880 \mathrm{~kg} \\
\text { Water- } 340 \mathrm{l} \\
\text { Fiber basalt- } 0,8 \\
\mathrm{~kg} \\
\mathrm{~V} / \mathrm{C} 0,4\end{array}$ \\
\hline 2 & $\begin{array}{l}\text { Bending, } \\
\text { beam } \\
40 \times 40 \times 16\end{array}$ & 6 & $\begin{array}{l}\text { Portland cement- } \\
860 \mathrm{~kg} \\
\text { Sand- } 504 \mathrm{~kg} \\
\text { Water }-3401 \\
\text { Fiber basalt- } 0,8 \\
\mathrm{~kg} \\
\text { Perlite- } 34 \mathrm{~kg} \\
\text { V / C } 0,4\end{array}$ & $\begin{array}{l}\text { Portland cement- } \\
860 \mathrm{~kg} \\
\text { Sand- } 620 \mathrm{~kg} \\
\text { Water- } 340 \mathrm{l} \\
\text { Fiber basalt- } 0,8 \\
\mathrm{~kg} \\
\text { Foam glass- } 80 \mathrm{~kg} \\
\text { V / C } 0,4\end{array}$ & $\begin{array}{l}\text { Portland ce- } \\
\text { ment- } 860 \mathrm{~kg} \\
\text { Sand }-880 \mathrm{~kg} \\
\text { Water }-3401 \\
\text { Fiber basalt- } 0,8 \\
\mathrm{~kg} \\
\mathrm{~V} / \mathrm{C} 0,4\end{array}$ \\
\hline 3 & $\begin{array}{l}\text { Thermal } \\
\text { conductivity, } \\
\text { plate } \\
150 \times 150 \times 20 \mathrm{~mm}\end{array}$ & 5 & $\begin{array}{l}\text { Portland cement- } \\
860 \mathrm{~kg} \\
\text { Sand }-504 \mathrm{~kg} \\
\text { Water- } 3401 \\
\text { Fiber basalt- } 0,8 \\
\mathrm{~kg} \\
\text { Perlite- } 34 \mathrm{~kg} \\
\text { V / C } 0,4\end{array}$ & $\begin{array}{l}\text { Portland cement- } \\
860 \mathrm{~kg} \\
\text { Sand- } 640 \mathrm{~kg} \\
\text { Water- } 320 \mathrm{l} \\
\text { Fiber basalt- } 0,8 \\
\mathrm{~kg} \\
\text { Foam glass- } 80 \\
\mathrm{~kg} \\
\mathrm{~V} / \mathrm{C} 0,4\end{array}$ & $\begin{array}{l}\text { Portland ce- } \\
\text { ment- } 860 \mathrm{~kg} \\
\text { Sand- } 880 \mathrm{~kg} \\
\text { Water }-3401 \\
\text { Fiber basalt- } 0,8 \\
\mathrm{~kg} \\
\mathrm{~V} / \mathrm{C} 0,4\end{array}$ \\
\hline
\end{tabular}

When preparing the $\mathrm{BFC}$ mixture, the consumption of materials was determined for each batch of the volume required for the manufacture of samples: cubes, prisms, plates of a cer- 
tain amount.Dry materials (Portland cement, aggregates, basalt fiber), designed for batching, were weighed on a balance with an error of $\pm 10 \mathrm{~g}$. Water was measured with an error of \pm 1 $\mathrm{g}$ with a measuring cylinder.

1 option (cooking BFC). Kneading is performed for the entire volume of samples for 3 options. First, the components are weighed dry. Further, water (3.412 1) is gradually introduced into the suspended cement $(8.42 \mathrm{~kg})$ with continuous stirring. Then a solution $(80 \mathrm{~g}$ in 1 liter of water) of a plasticizer is introduced into the resulting mixture. In the process of further thorough mixing, basalt fiber is added. The mixing process continues until complete separation of the filaments of the fiber. At the final stage, a quartz crystal $(8.62 \mathrm{~kg})$ is introduced. Before setting, the prepared mixture is placed in pre-lubricated forms (Emulsol EKS-A).

2 option (cooking BFCwith the addition of granulated foam glass). A porous insulation material - granulated foam glass (3.412 1) is introduced into the cement milk prepared according to the above technology with a plasticizer. Then $6,120 \mathrm{~kg}$ sand is added.

After introducing the porous insulation into the cement-sand mixture, the resulting composition is thoroughly mixed and, before the concrete mixture begins to set, it is placed in pre-prepared forms (figure 1). Sealed with hand by bayonet.

3 option (Preparation of BFC with the addition of expanded perlite). In general, the technology for preparing a concrete mixture is similar to that used in the first and second options. After adding sand to the cement mixture and thoroughly mixing, perlite (335gr.) is added to the composition. Justification of the mass fraction of pearlite was made on the basis of data on the bulk density of the components.

All experimental samples remain in the laboratory until complete solidification and strength gain, where they are provided with NTU in accordance with STST 10180-90: temperature $+20^{\circ} \mathrm{C}$, humidity $95 \%$. The holding time is 28 days. Samples are marked on the upper face with the date of manufacture and the type of concrete.

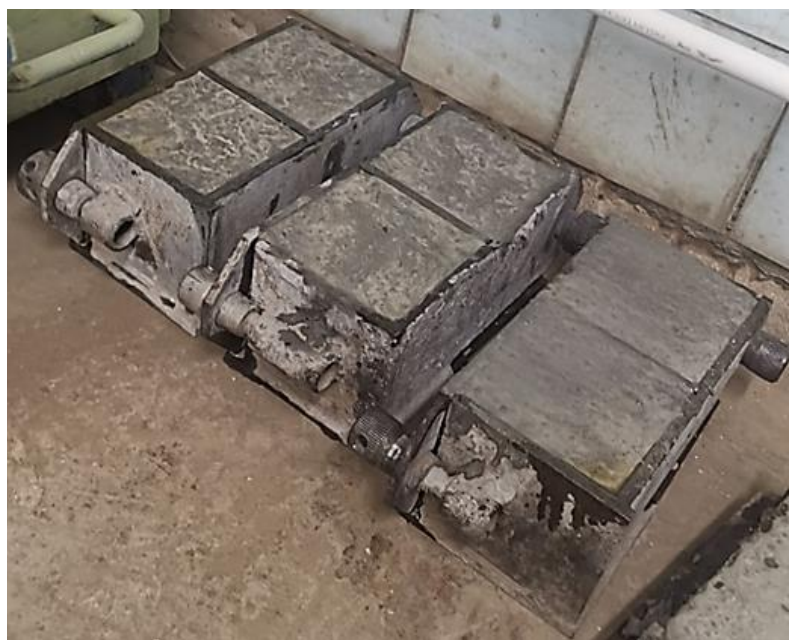

Fig. 1. General view of samples for determining the strength in axial compression

Determination of the strength of concrete consists in measuring the minimum forces destroying specially made control concrete specimens under static loading at a constant rate of load growth, and then calculating the stresses under these forces.

The room for testing samples is provided with a temperature of $(20 \pm 5){ }^{\circ} \mathrm{C}$ and a relative humidity of at least $55 \%$. The samples were held before testing in a stripped form for 24 hours. 
After a detailed examination of the samples, weighing and measurement of each of them was carried out in order to determine the density and refine the geometric parameters.

To test the samples, we used a test press TP-1-1500, manufactured by TESTPRESS LLC, which meets the requirements of STST 28840-90.

Compression test of specimens. Before placing the specimen in the testing machine, concrete particles from the previous test on the base plates of the testing machine were carefully removed. After installation, the sample is loaded to failure (figure 2) at a constant rate of load rise $(0.6 \pm 0.2) \mathrm{MPa} / \mathrm{s}$. The maximum force achieved during the test is taken as the breaking load. After testing all images of the series, the arithmetic mean value is determined and taken as the final result.

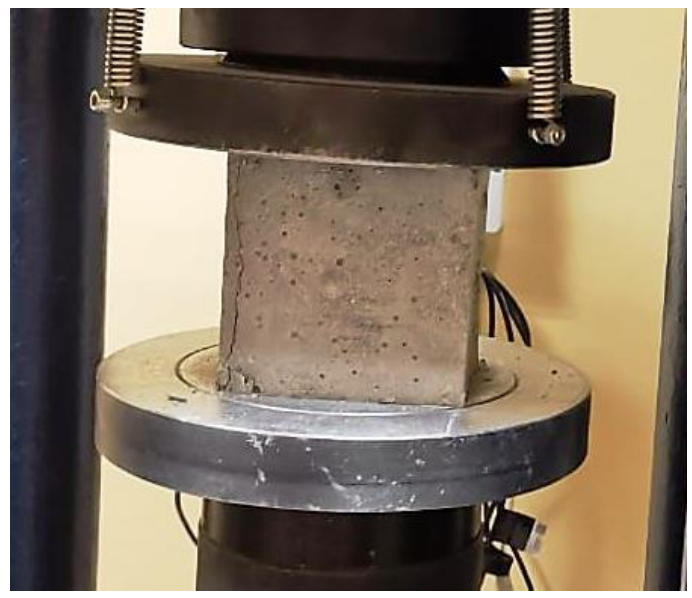

Fig. 2. Destruction of the sample under axial compression

The test results are presented in table 4.

Table 4. Test result of samples - cubes with an edge of $100 \mathrm{~mm}$

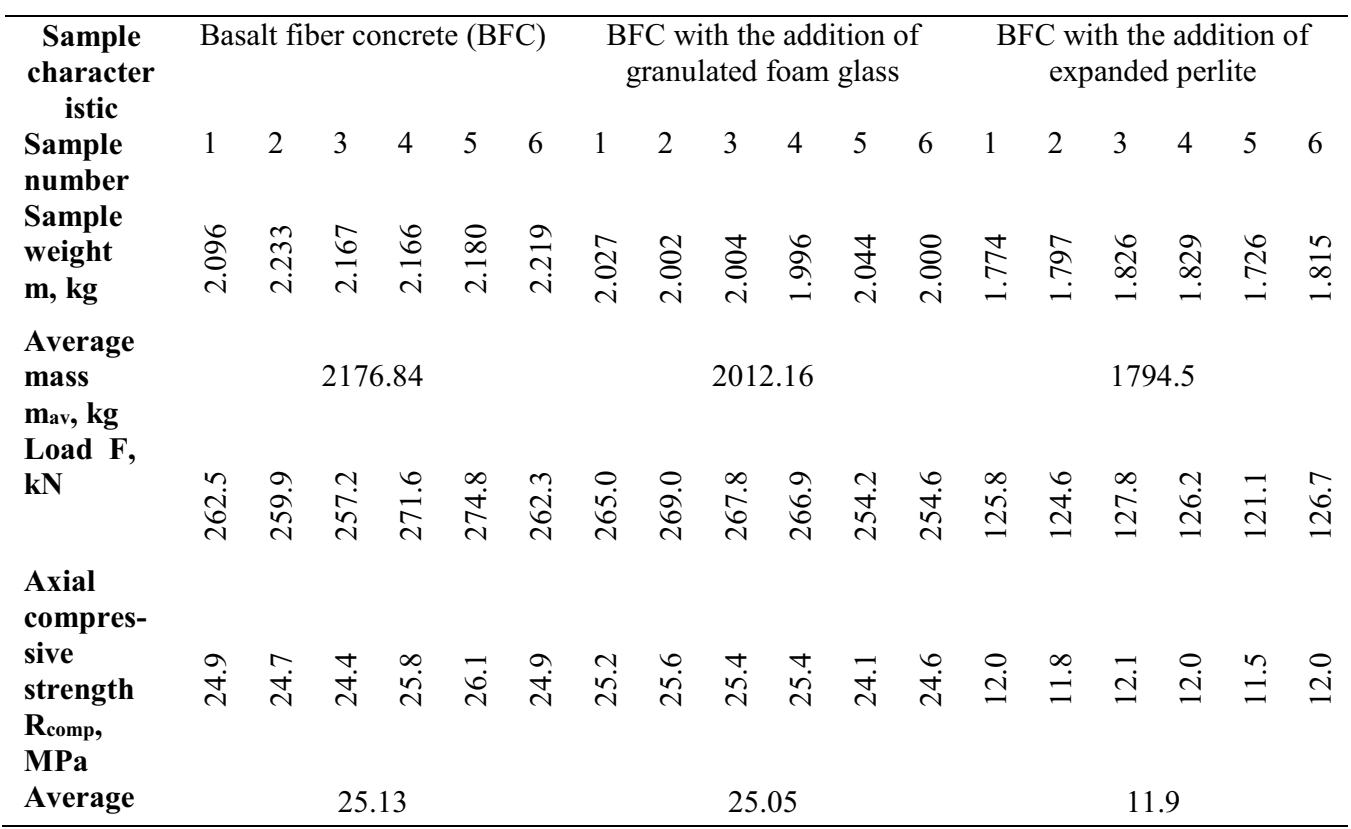




\section{strength \\ $\overline{\boldsymbol{R}}_{\text {comp }}$ \\ MPa}

Based on the data obtained, a diagram of the compressive strength of the test samples is constructed (figure 3), which demonstrates the increase in the strength of the material with an increase in its density.

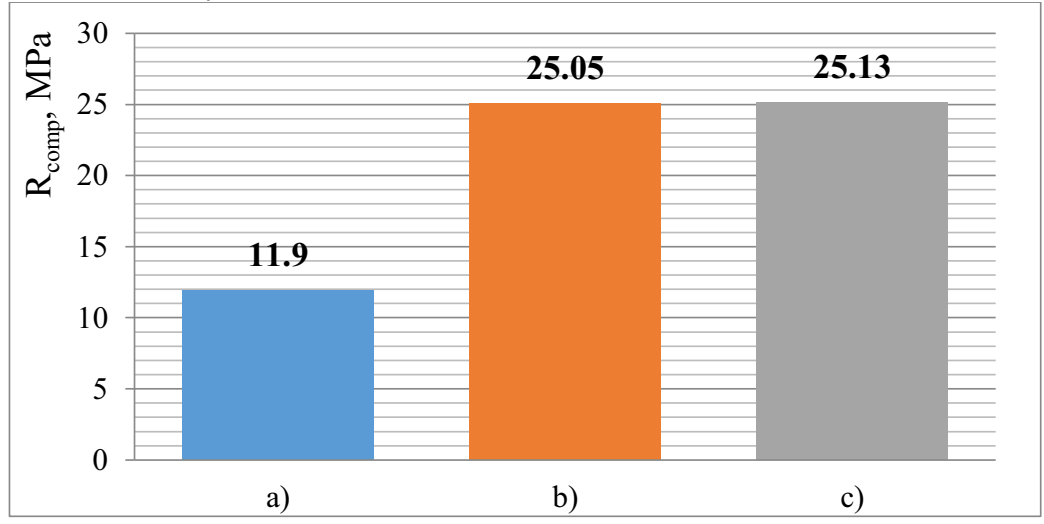

Fig. 3. Diagram of the compressive strength ( $\mathrm{R}_{\text {comp }}$ ) of the test samples:a) BFC with the addition of expanded perlite; b) BFC with the addition of granulated foam glass; c) BFC.

Bending tensile test. The sample is placed on two supports and a concentrated load is applied in the center of the prism. Using a hydraulic press, the specimen is loaded at a constant rate of load growth $(0.05 \pm 0.01) \mathrm{MPa} / \mathrm{s}$ until its destruction (figure 4$)$. The experimental results are presented in table 5.

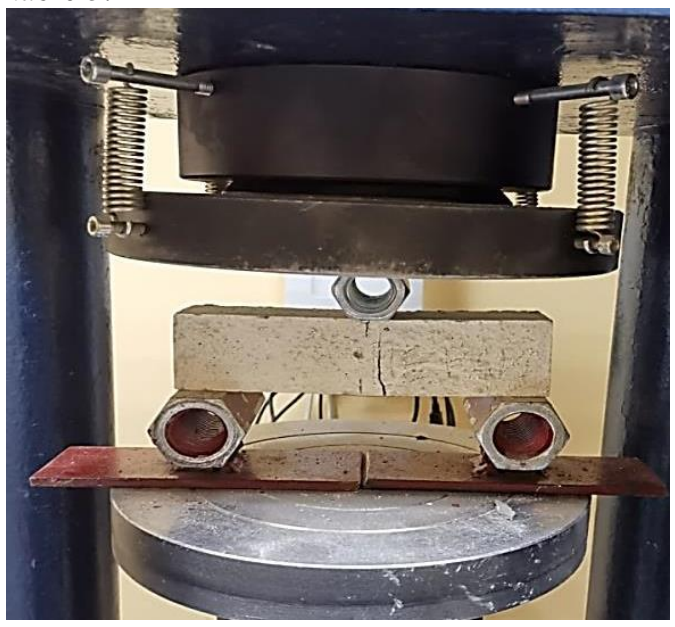

Fig.4. Failure of a specimen in bending

Table 5. Test results of samples - prisms of $40 \times 40 \times 160 \mathrm{~mm}$.

\begin{tabular}{cccccccccccccccccccccc}
\hline $\begin{array}{c}\text { Sample } \\
\text { character } \\
\text { istic }\end{array}$ & \multicolumn{1}{c}{ Bazaltfiber concrete (BFC) } & $\begin{array}{c}\text { BFC with the addition of } \\
\text { granulated foam glass }\end{array}$ & \multicolumn{8}{c}{$\begin{array}{c}\text { BFC with the addition of } \\
\text { expanded perlite }\end{array}$} \\
$\begin{array}{c}\text { Sample } \\
\text { number }\end{array}$ & 1 & 2 & 3 & 4 & 5 & 6 & 1 & 2 & 3 & 4 & 5 & 6 & 1 & 2 & 3 & 4 & 5 & 6
\end{tabular}




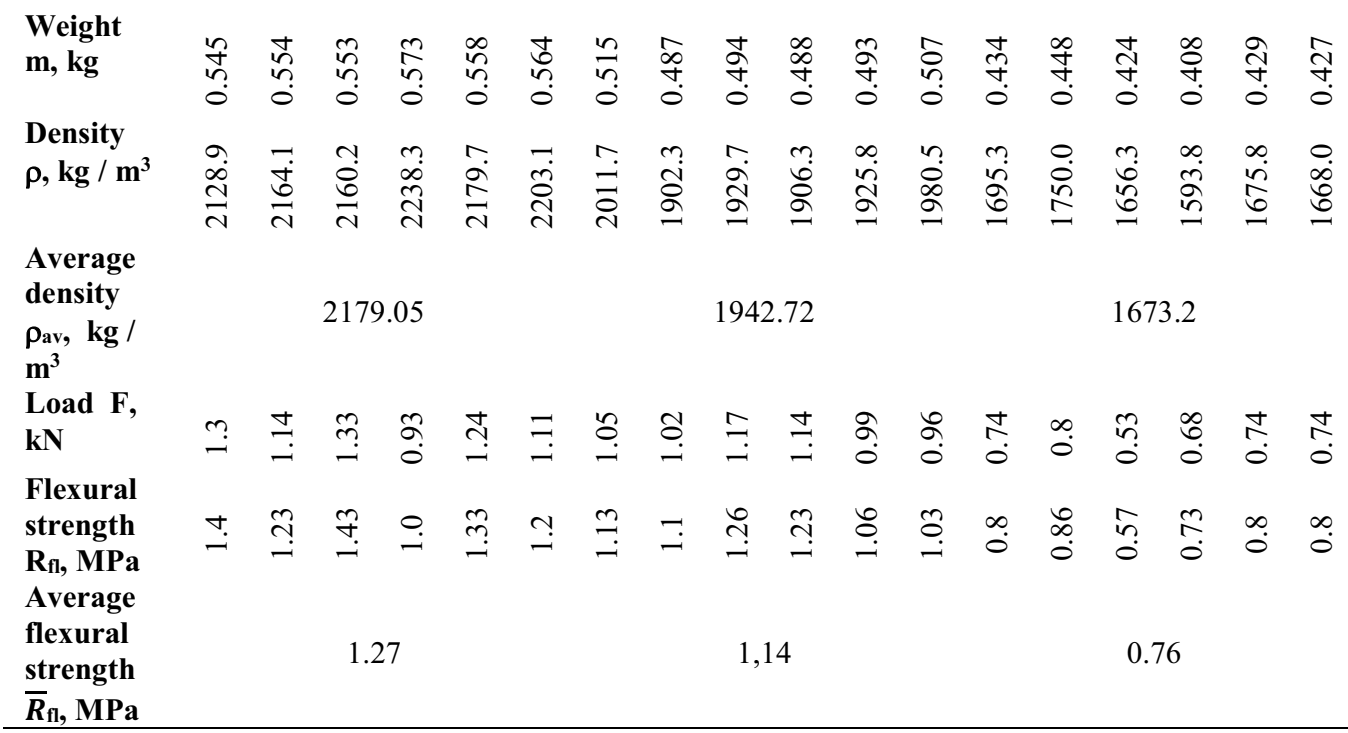

Based on the data in table 5, a graph of the relationship between the flexural strength of the tested concrete and its density is plotted (figure 5). The graph clearly shows an increase in the bending strength of the sample with an increase in density values.

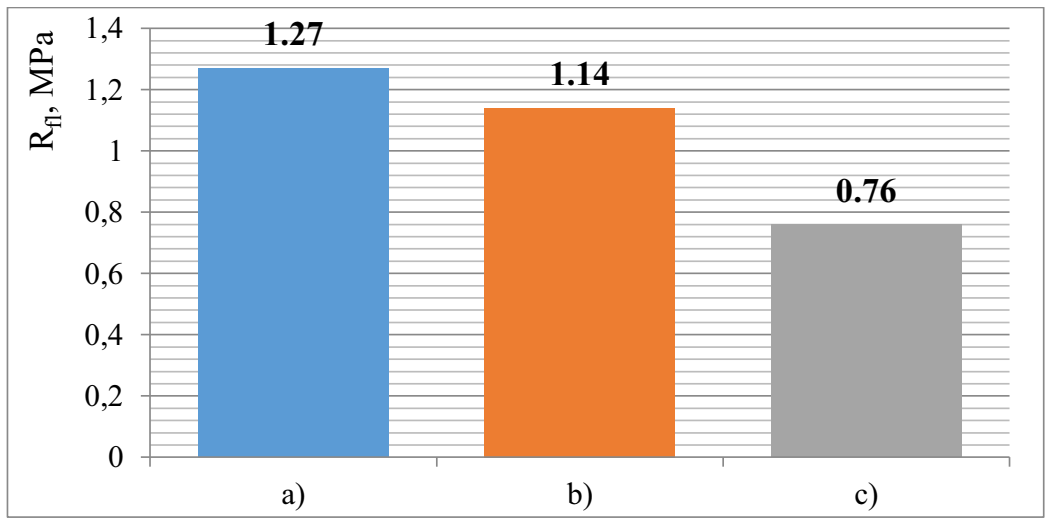

Fig.5. Diagram of bending strength of test specimens: a) BFC; b) BFC with the addition of granulated foam glass;c) BFC with the addition of expanded perlite.

Determination of thermal conductivity of materials.In order to study the thermomechanical properties of materials, the value of thermal conductivity $\lambda$ is required. For this, a method was used to determine the thermal conductivity and thermal resistance in a stationary thermal regime. In accordance with the requirements of STST 7076-99 for the experiment using the above described technology, the required number of samples were made with dimensions of $150 \times 150 \times 20 \mathrm{~mm}$, respectively, BFC (No. 1), BFC with the addition of perlite (No. 2) and $\mathrm{BFC}$ with the addition of granulated foam glass(No. 3).

The study was carried out on an ITS-1 device.

The principle of operation of the device is based on the creation of a stationary heat flux passing through the flat sample under study (heat flux at which all the considered thermophysical parameters do not change with time), according to the magnitude of which, 
the temperature of the opposite faces of the sample and its thickness, the thermal conductivity of the sample is calculated $\lambda$.

After inspection and verification of the geometric parameters, the test specimen is placed in the measuring cell between the refrigerator and the heating plates of the device and fixed with the necessary force (figure 6).

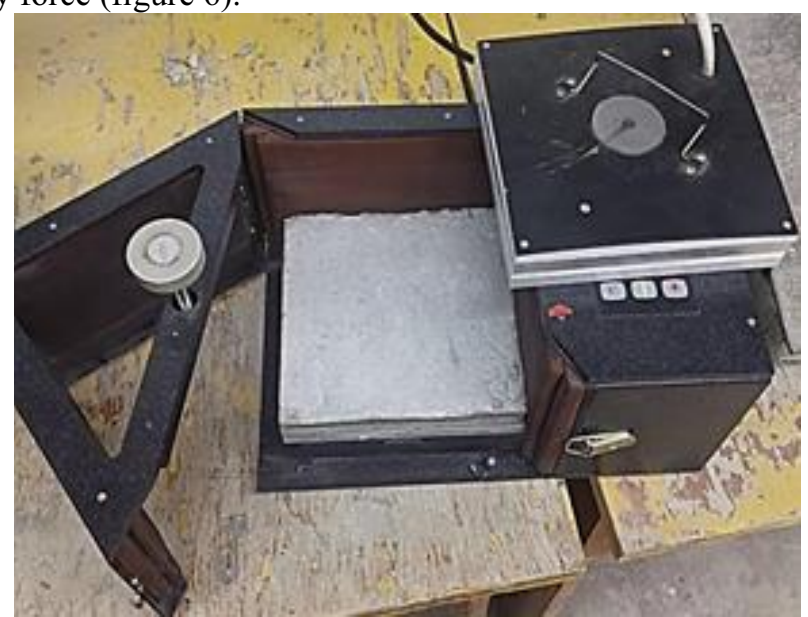

Fig. 6. The sample and apparatus for determination of thermal conductivity

The results obtained during the measurement are summarized in table 6 .

\begin{tabular}{|c|c|c|c|c|c|c|c|c|c|c|c|c|c|c|c|}
\hline $\begin{array}{c}\text { Sample } \\
\text { characteristic }\end{array}$ & \multicolumn{5}{|c|}{$\begin{array}{l}\text { Bazalt fiber concrete } \\
\text { (BFC) }\end{array}$} & \multicolumn{5}{|c|}{$\begin{array}{l}\text { BFC with the addition of } \\
\text { granulated foam glass }\end{array}$} & \multicolumn{5}{|c|}{$\begin{array}{l}\text { BFC with the addition of } \\
\text { expanded perlite }\end{array}$} \\
\hline $\begin{array}{l}\text { Sample } \\
\text { number }\end{array}$ & 1 & 2 & 3 & 4 & 5 & 1 & 2 & 3 & 4 & 5 & 1 & 2 & 3 & 4 & 5 \\
\hline Weight m, kg & $\stackrel{\infty}{2}$ & 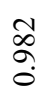 & $\frac{\infty}{5}$ & 离 & 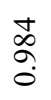 & $\begin{array}{l}+1 \\
\infty \\
0 \\
0\end{array}$ & $\begin{array}{l}\infty \\
\infty \\
\infty \\
0 \\
0\end{array}$ & 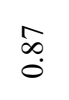 & $\begin{array}{l}\infty \\
\infty \\
0\end{array}$ & \begin{tabular}{l}
\multirow{2}{*}{} \\
$\infty$ \\
0 \\
0
\end{tabular} & $\frac{\pi}{\check{c}}$ & $\stackrel{\substack{+i}}{i}$ & 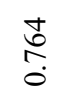 & $\stackrel{n}{\stackrel{n}{0}}$ & $\frac{\stackrel{9}{+}}{\stackrel{0}{0}}$ \\
\hline $\begin{array}{l}\text { Thickness d, } \\
\text { mm }\end{array}$ & $\stackrel{\leftrightarrow}{\circ}$ & $\stackrel{\circ}{9}$ & $\begin{array}{l}0 \\
\infty\end{array}$ & $\stackrel{m}{\infty}$ & $\stackrel{\circ}{9}$ & $\stackrel{\infty}{\infty}$ & $\stackrel{+}{\infty}$ & $\underset{\infty}{\stackrel{+}{\infty}}$ & $\stackrel{\infty}{\infty}$ & $\underset{\infty}{-}$ & $\stackrel{m}{\infty}$ & $\vec{\infty}$ & $\begin{array}{l}\infty \\
\infty \\
\infty\end{array}$ & $\stackrel{\circ}{9}$ & $\begin{array}{l}n \\
\infty \\
\infty\end{array}$ \\
\hline $\begin{array}{l}\text { Thermal } \\
\text { conductivity } \\
\lambda, W /(m K)\end{array}$ & 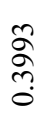 & ڤั & 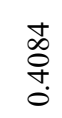 & 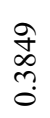 & 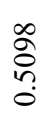 & $\begin{array}{l}\text { } \\
\stackrel{1}{0} \\
0\end{array}$ & $\frac{n}{a}$ & 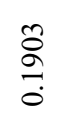 & $\begin{array}{l}0 \\
\stackrel{0}{1} \\
0\end{array}$ & $\frac{2}{2}$ & 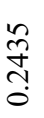 & $\begin{array}{l}\hat{\curvearrowright} \\
\text { ָे }\end{array}$ & 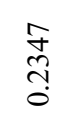 & 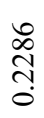 & 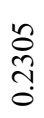 \\
\hline $\begin{array}{l}\text { Average } \\
\text { thermal con- } \\
\text { ductivity } \bar{\lambda}, \\
\text { W/(m K ) }\end{array}$ & & & 0.420 & & & & & .1999 & & & & & 0.246 & & \\
\hline $\begin{array}{l}\text { Thermal re- } \\
\text { sistance } R \text {, } \\
\mathbf{m}^{2} \cdot \mathbf{K} / \mathbf{W}\end{array}$ & 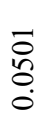 & $\begin{array}{l}\frac{n}{0} \\
\stackrel{5}{0} \\
\stackrel{0}{0}\end{array}$ & $\begin{array}{l}n \\
n \\
0 \\
0\end{array}$ & $\begin{array}{l}\frac{n}{5} \\
\stackrel{+}{0} \\
\stackrel{0}{0}\end{array}$ & 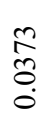 & 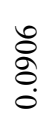 & 令 & $\begin{array}{l}\hat{\delta} \\
8 \\
0\end{array}$ & $\begin{array}{l}\tilde{0} \\
0 \\
0 \\
0\end{array}$ & $\begin{array}{l}\hat{\Omega} \\
\text { ọ } \\
\stackrel{0}{0}\end{array}$ & $\stackrel{n}{5}$ & $\begin{array}{l}\infty \\
\stackrel{0}{0} \\
0\end{array}$ & ồ & $\begin{array}{l}\overrightarrow{\hat{\delta}} \\
0 \\
0 \\
0\end{array}$ & $\begin{array}{l}0 \\
\stackrel{1}{0} \\
0 \\
0 \\
0\end{array}$ \\
\hline 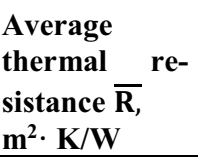 & & & .045 & & & & & .0919 & & & & & .0763 & & \\
\hline
\end{tabular}

Table6. Results of measuring the thermal conductivity of the samples 
Based on the results of the experiment, diagrams of thermal conductivity $(\lambda, \mathrm{W} / \mathrm{m} \cdot \mathrm{K})$ and thermal resistance $\left(\mathrm{R}, \mathrm{m}^{2} \cdot \mathrm{K} / \mathrm{W}\right)$ test samples (figures 7 and 8 ). When analyzing the results, it can be seen that the lowest thermal conductivity is possessed by samples of BFB with the addition of foam glass.

\section{Results}

To obtain a new heat-efficient material, granulated foam glass is introduced into the BFC mixture. Experimental composition of the BFC mixture with foam glass: 1: 0.75: 0.4, the content of cement-sand-foam glass. The final thermal conductivity of the mixture obtained was $\lambda \mathrm{n}=0.14 \mathrm{~W} /\left(\mathrm{m} \cdot{ }^{\circ} \mathrm{C}\right)$.

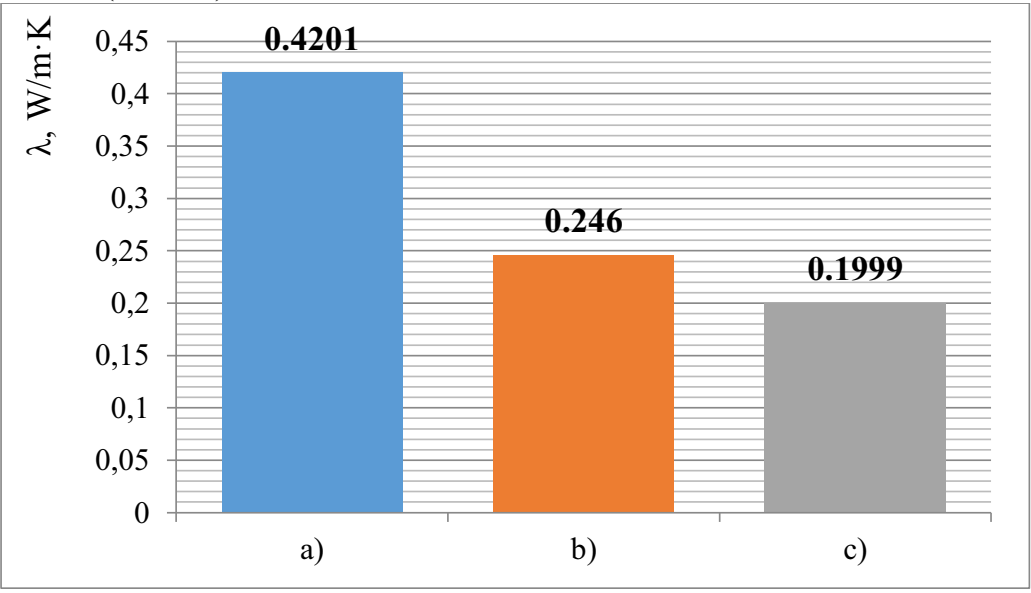

Fig. 7. Diagram of the thermal conductivity of the samples under study: a)BFC; b) BFC with the addition of expanded perlite; c) BFC with the addition of granulated foam glass.

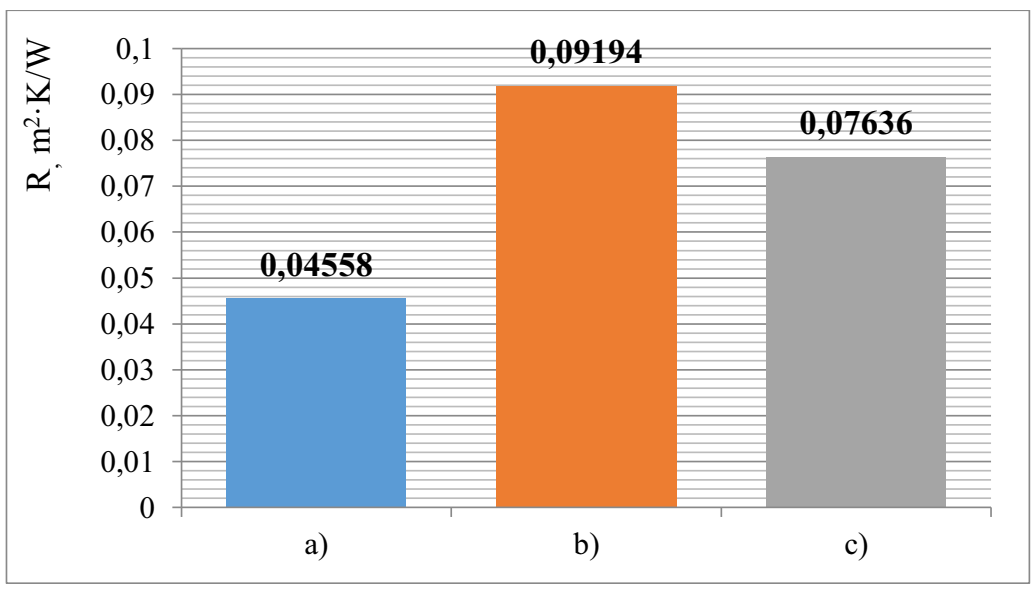

Fig. 8. Diagram of the thermal resistance of the samples under study: a) BFC; b) BFC with the addition of expanded perlite; c) BFC with the addition of granulated foam glass.

In order to assess the technological effect from the use of a heat-efficient BFC, the thickness of the enclosing structure was calculated from various structural and structural-thermal insulation materials in accordance with the requirements of STST 10180-2012, STST 10181- 
2014, STST 28570-2019 and STST 7076-99. The physical and mechanical characteristics of materials and the results of calculations are presented in table 7.

Table7. Physical and mechanical characteristics of compared materials

\begin{tabular}{lccccc}
\hline Parameter & $\begin{array}{c}\text { BFC with the } \\
\text { addition of } \\
\text { granulated } \\
\text { foam glass }\end{array}$ & $\begin{array}{c}\text { BFC with the } \\
\text { addition of } \\
\text { expanded per- } \\
\text { lite }\end{array}$ & $\begin{array}{c}\text { Foam } \\
\text { concrete }\end{array}$ & $\begin{array}{c}\text { Bazalt fiber } \\
\text { concrete } \\
\text { (BFC) }\end{array}$ & Heavy concrete \\
$\boldsymbol{\lambda}_{\mathbf{A} \mathbf{1}, \mathbf{W} / \mathbf{m K})}$ & 0.12 & 0.22 & 0.25 & 0.8 & 1.7 \\
$\mathbf{\rho}, \mathbf{~} \mathbf{g} / \mathbf{m}^{\mathbf{3}}$ & 1200 & 1000 & 800 & 1850 & 2500 \\
$\boldsymbol{\Delta}, \mathbf{m}$ & 0.14 & 0.25 & 0.28 & 0.89 & 1.89 \\
\hline
\end{tabular}

The graph of the relationship between the thermal conductivity coefficient and the density of materials is shown in figure 8 . The relationship between the thickness of the enclosing structure and the thermal conductivity coefficient is illustrated in figure 9.

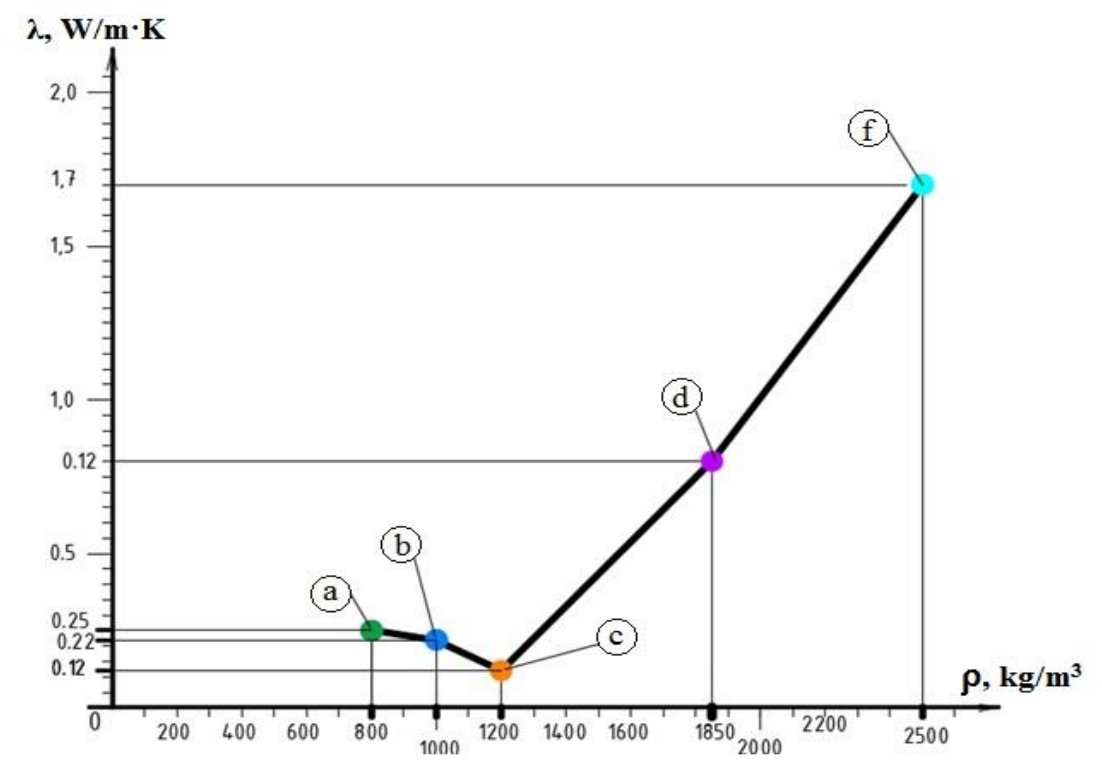

Fig. 9. Dependence of the thermal conductivity coefficient on the density of the material: a) foam concrete; b) perlite concrete; C) BFC with the addition of foam glass, d) BFC and f) heavy concrete.

Dependence of the thickness of the enclosing structure on the coefficient of thermal conductivity $\lambda, \mathrm{W} / \mathrm{m} \cdot \mathrm{K}$ is illustrated in figure 10 . The figure shows the results of calculations of the thickness of enclosing structures $\Delta, \mathrm{m}$, under the same operating conditions of the designed building. 


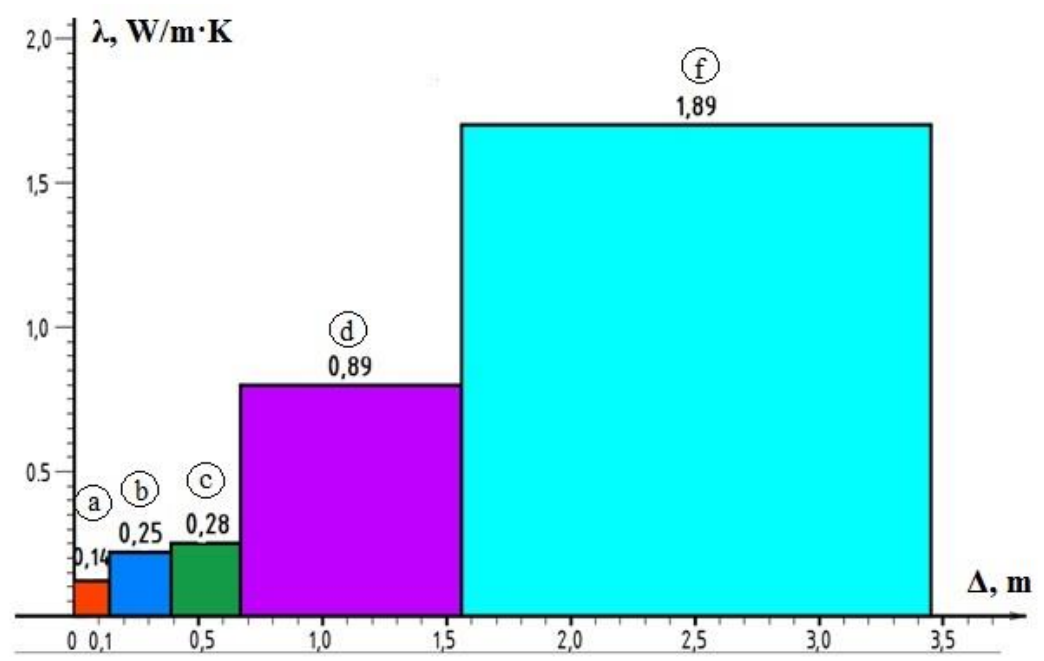

Fig. 10. Relationship between the thickness of the enclosing structure and the thermal conductivity coefficient: a) BFCwith the addition of foam glass; b) perlite concrete; C) foam concrete, d) BFC and f) heavy concrete.

According to the results of the theoretical thermal engineering calculation, it can be seen that the use of foam glass as a heat-efficient additive in the BFC mixture reduces the thickness of the structural material by 6 times. BFC with a pearlite filler also has a fairly low thermal conductivity, the structure thickness of which is 3.5 times less than that of a BFC with a quartz sand filler.

Evaluating the results of the studies carried out, we can state the following. Vaulted structures made of monolithic fiber-reinforced concrete were previously designed mainly «cold» due to the thin-walled load-bearing and enclosing structures. Since these structures have curvilinear outlines, the use of traditional heat-insulating materials, for example, expanded polystyrene board, is practically impossible. Until now, the most acceptable was the insulation by spraying polyurethane foam on the inner surface of the arches, which entailed a significant increase in labor costs and the cost of construction. And the very technology of construction of such structures, implying gunning of concrete mixtures, in the case of the device of multilayer monolithic coatings, loses its effectiveness.

The use of the proposed heat-efficient fiber-reinforced concrete, suitable for application on surfaces of various geometries by gunning [25, 26], will not only increase the scope of such structures by increasing their performance, but also significantly reduce labor costs for their construction in a monolayer version. In addition, an additional effect will be a decrease in the total material consumption of vaults and an increase in the building volume obtained from a decrease in the thickness of the enclosing structures.

\section{Conclusions}

As a result of the research carried out, methods for increasing the thermal efficiency of fiberreinforced concrete have been theoretically substantiated and experimentally demonstrated. At the same time, the following theoretical and practical data were obtained:

1. Based on the results of analytical studies, the composition of dispersed-reinforced concrete with basalt fiber using heat-efficient aggregates was selected. 
2. Experimental studies were carried out and reliable indicators of the compressive strength of heat-efficient BFC were obtained, which amounted to: BFC $25.13 \mathrm{MPa}$, BFC with the addition of pearlite 11.9 MPa, BFC with the addition of foam glass $25.05 \mathrm{MPa}$.

3. Experimental studies were carried out and reliable indicators of the bending strength of heat-efficient BFC were obtained, which amounted to: BFC 1.27 MPa, BFC with the addition of pearlite $0.76 \mathrm{MPa}, \mathrm{BFC}$ with the addition of foam glass $1.14 \mathrm{MPa}$.

4. Experimental studies were carried out and reliable indicators of thermal conductivity of heat-efficient BFC were obtained, which amounted to: BFC $0.4021 \mathrm{~W} /(\mathrm{m} * \mathrm{~K})$, BFC with the addition of pearlite $0.246 \mathrm{~W} /(\mathrm{m} * \mathrm{~K})$ and $\mathrm{BFC}$ with the addition of foam glass $0.1999 \mathrm{~W}$ / ( $\mathrm{m} * \mathrm{~K})$.

5. Based on the results of the data obtained experimentally, the analysis and selection of the most energy-efficient aggregate for fiber-reinforced concrete - granulated foam glass was made.

6. Based on the performed heat engineering calculations, comparative data on the thickness of the enclosing structures made of traditional and proposed materials were obtained.

\section{References}

1. B.M. Shoikhet, Energy efficient building concept. European experience, Energy saving 7, 62-65 (2007)

2. A.N. Davidyuk, G.V. Nesvetaev, Effective materials and structures for solving the problem of energy saving in buildings, Housing construction 3, 16 - 18 (2010)

3. D.A. Kazakov, M.S. Kravchenko, Advantages of using basalt-fiber-reinforced concrete in construction, Scientific Bulletin of the Voronezh State University of Architecture and Civil Engineering. Student and Science 1(8), 33-37 (2019)

4. F.N. Rabinovich, Composites based on dispersed-reinforced concrete. Questions of theory and design, technology, construction (Publishing house ASV, Moscow, 2011)

5. A.D. Zhukov, V.A. Rudnitskaya, T.V. Smirnova, Reinforcing fibers in concrete technology / A.D. Zhukov, Bulletin of MGSU 4, 160-164 (2012)

6. I.A. Voilokov, S.F. Kanaev, Basalt fiber concrete. Historical excursion, Engineering and construction journal 4, 26-31 (2009).

7. Vishal Pandurang Kumbhar Basalt Rock Fibers - New Construction Material // Acta Engineering International 2(1) 11-18 (2014)

8. S.N. Karaburc, S.A. Yildizel, G.C. Calis, Evaluation of the basalt fiber reinforced pumice lightweight concrete, Magazine of Civil Engineering 94(2), 81-92 (2020) doi: 10.18720 / MCE.94.7.

9. A.A. Baranova, A.A. Bobrova, Dispersed reinforcement of cellular and fine-grained concrete based on microsilica, Proceedings of universities. Investments. Construction. Property 9(4), 694-703 (2019) doi.org/10.21285/2227-2917-2019-4-694-703.

10. L.A. Urkhanova, S.A. Lkhasaranov, S.L. Buyantuev, R.S. Fedyuk, A.V. Taskin, Reducing alkaline corrosion of basalt fiber in concrete, Engineering and construction journal 7(91), 112-120 (2019) doi: 10.18720 / MCE.91.10.

11. Paschal Chimeremeze Chiadighikaobi, Effects of basalt fiber in lightweight expanded clay concrete on compres-sive strength and flexural strength of lightweight basalt fiber reinforced concrete, IOP Conference Series Ma terials Science and Engineering 640(1), 
012055 1-9 (2019) doi: 10.1088 / 1757-899X / 640/1/012055. Project: Basalt Fiber in Civil Engineering.

12. A.L. Popov, V.V. Strokova, Fiber-foam concrete of autoclave hardening using a composite binder, Building materials 5, 38-44 (2019) doi.org/10.31659/0585-430X2019-770-5-38-44.

13. A.N. Tkachenko, D.A. Kazakov, Pat. No. 2615202 Russian Federation, IPC E04G 11/04 (2006.01). The method of erection of wavy monolithic vaults and formwork for its implementation, applicant and patentee: Federal State Budgetary Educational Institution of Higher Education Voronezh State Technical University. - Application: 2014130694, 07.24.2014 Published: 04.04.2017 Bul. No. 10 - 5 p.

14. A.N. Tkachenko, D.A. Kazakov, V.N. Melkumov, Innovative pneumotechnology for the construction of fiber-reinforced structures, Scientific Bulletin of the Voronezh State University of Architecture and Civil Engineering. Construction and architecture 4(36), 11-21 (2014)

15. B.M. Rumyantsev, A.D. Zhukov, T.V. Smirnova, Energy efficiency and methodology for creating heat-insulating materials, Internet Bulletin of VolgSUACE 4(35), 3 (2014)

16. D.A. Kazakov, D.P. Vorzheva, Establishment of rational parameters of basalt-fiberconcrete mixture for gunningapplication, Scientific Bulletin of the Voronezh State University of Architecture and Civil Engineering. Student and Science 1(8), 78-83 (2019)

17. D.A. Kazakov, A.S. Ovcharenko, A.O. Mitina, E. D. Kazakova, On the question of the technology of device monolithic structures made of concrete on heat-efficient aggregates, Construction and real estate. Scientific journal ISSN 2618-9933 1(5), 44-53 (2020)

18. S.Yu. Natsievsky, Perlite-based heat-efficient building materials, Building materials 6, 52-54 (2011)

19. E.V. Miroshnikov, Nanostructured perlite binder and foam concrete based on it (author. diss. for a job. uch. Art. Cand. of tech. sciences, Belgorod, 2010)

20. A.V. Komkova, M.P. Rachinskaya, Foam glass and its application in Russia, Modern scientific research and innovation 5, 18 (2012)

21. S.I. Puzanov, Features of the use of materials based on cullet as fillers for Portland cement concrete, Building materials, 12-14 (2007)

22. R.G. Melkonyan, B.I. Beletsky, G.R. Melkonyan, Foam glass. Theory and practice of the production of silicate foams, Glass of the World 1, 32-59 (2011)

23. A.A. Pashkevich, D.V. Oreshkin, O.B. Lyapidevskaya, Dry construction mixtures with hollow microspheres, In the collection: Reliability and durability of building materials, structures and foundations, materials of the $\mathrm{V}$ International scientific and technical conference: in 3 parts, 207-211 (2009)

24. A.I. Inozemtsev, E.V. Korolev, Hollow microspheres - an effective filler for highstrength lightweight concrete, Industrial and civil engineering, 80-83 (2013)

25. A.O. Mitina, D.A. Kazakov, Technologies for the construction of monolithic structures made of concrete on heat-efficient aggregates, Construction and real estate of the Voronezh State Technical University. Construction and real estate 1(5), 44-53 (2020)

26. A.S. Ovcharenko, D.A. Kazakov, Analysis of the technological parameters of concreting during the construction of fiber-reinforced vaults on pneumatic formwork. Technology, 
organization, planning and construction management, Construction and Real Estate of the Voronezh State Technical University. Construction and real estate 1(4), 50-55 (2019) 